\title{
Xenopus Egg Extract Treatment Reduced Global DNA Methylation of Donor Cells and Enhanced Somatic Cell Nuclear Transfer Embryo Development in Pigs
}

\author{
Xiaoyu Yang, ${ }^{1,2, *}$ Jiude Mao, ${ }^{1,3, *}$ Eric M. Walters, ${ }^{1,3}$ Ming-Tao Zhao, ${ }^{1}$ Jennifer Teson, ${ }^{1}$ \\ Kiho Lee, ${ }^{1}$ and Randall S. Prather ${ }^{1,3}$
}

\begin{abstract}
The efficiency to produce offspring by somatic cell nuclear transfer (SCNT) is low. It has been showed that treatment of donor cells with Xenopus oocyte extract increased live births in ovine and handmade cloned embryo development in pigs. Scriptaid treatment after oocyte activation is another approach to improve SCNT efficiency. The present study was carried out to investigate (a) the effects of treatment of donor cells with Xenopus egg extract on donor cell DNA methylation at days 0 and 4 with two digitonin permeabilization concentrations (10 and $15 \mu \mathrm{g} / \mathrm{mL}$ ), (b) the effects of treatment of donor cells with Xenopus egg extract on early development of cloned embryos, and (c) the effects of combined treatments, treating donor cells with extract before nuclear transfer and treatment of cloned embryos with scriptaid after oocyte activation, on embryo development. Compared to the control, a decrease of DNA methylation in donor cells was observed at $2.5 \mathrm{~h}$ after extract treatment. However, this effect was not observed after the cells were cultured for four more days. More embryos developed into blastocysts in the Xenopus egg extract-treated group than in the control $(13.4 \pm 1.9 \%$ vs. $9.1 \pm 1.9 \%, p=0.01)$. Furthermore, scriptaid treatment of cloned embryos further increased the frequency of development to blastocyst, compared to the control reconstructed with the same extract-treated cells $(22.5 \pm 0.9 \%$ vs. $15.3 \pm 0.9 \%, p<0.01)$. In addition, egg extract treatments increased the cell number in the blastocysts. This study demonstrated that Xenopus egg extract treatment reduced donor cell DNA methylation and enhanced the SCNT embryo development. Moreover, the combined treatments of donor cells with egg extract before nuclear transfer and of cloned embryos with scriptaid could improve cloned embryo development additively.
\end{abstract}

Key words: embryo development; pig; scriptaid; somatic cell nuclear transfer; Xenopus egg extract

\section{Introduction}

S OMATIC CELL NUCLEAR transfer (SCNT) has been a major practical approach to produce genetically modified pigs as biomedical models to study human diseases ${ }^{1-3}$ and as sources of organs in xenotransplantation research, ${ }^{4}$ since pig organ size, anatomy, and physiology are similar to humans. Genetically modified pigs could improve production agriculture as well. ${ }^{5,6}$ However, the efficiency to produce pigs by SCNT is low. In addition, various abnormalities have been reported in SCNT-derived animals. ${ }^{2}$ The low cloning efficiency and developmental problems associated with
SCNT are thought to be caused by inadequate nuclear remodeling and reprogramming of the donor nucleus. ${ }^{7}$ In fact, it has been shown that although reprogramming in SCNT embryos is similar to the reprogramming that occurs after fertilization, these events are delayed and incomplete. ${ }^{8}$

The mature oocyte cytoplasm can remodel differentiated nuclei of somatic cells to produce offspring., ${ }^{2,9,10}$ Remodeling of the nuclei takes place immediately after nuclear transfer. This process has not been fully characterized, but does involve epigenetic changes such as histone modification and DNA methylation. After nuclear transfer into an enucleated metaphase II (MII) oocyte, chromosomal protein mobility is

\footnotetext{
${ }^{1}$ Division of Animal Sciences and ${ }^{3}$ National Swine Resource and Research Center, University of Missouri, Columbia, Missouri.

${ }^{2}$ Key Laboratory of Stem Cell and Regenerative Medicine, Center of Cell Developmental Biology, College of Preclinical Medicine, Fujian Medical University, Fuzhou, P.R. China.

*These two authors contributed equally to this work.
} 
increased; the somatic type linker histone $\mathrm{H} 1$ is replaced with embryonic type linker histone B4 in Xenopus ${ }^{11,12}$ and H1FOO in the mouse. ${ }^{13,14}$ Another very critical characterization of remodeling is DNA de-methylation ${ }^{15}$ and transcriptional reprogramming to lead to pluripotent gene activation and expression. ${ }^{12,16}$ Thus, the somatic cell nucleus is remodeled and reprogrammed to a pluripotent status. Further study showed that uptake of an oocyte-specific linker histone is required for transcriptional reprogramming of pluripotent genes (Sox2 and Oct4). ${ }^{11,12}$ All these findings led to the use of cell-free systems from oocyte extracts to study nuclear programming. Extract from MI and MII oocytes, ${ }^{12}$ early embryo blastomeres, ${ }^{17}$ and embryonic stem cells ${ }^{18,19}$ can reprogram somatic cell nuclei to a pluripotent status. Extract from these types of cells have also been used to study SCNT embryo development capabilities. Treatment of donor cells with mammalian or Xenopus oocyte extract before SCNT resulted in a threefold increase in the production of cloned offspring in murine $\mathrm{e}^{20}$ and a fourfold increase in ovine $^{21}$ and improved in vitro development of cloned embryos in bovine ${ }^{22}$ and in handmade pig-cloned embryos. ${ }^{23}$

Another new approach to improve cloning efficiency is treatment of cloned embryos with scriptaid immediately after the somatic cell is fused with the enucleated oocyte. Scriptaid is a histone deacetylase inhibitor (HDACi) that belongs to an existing class of hydroxamic acid-containing HDACi. Increased acetylation results in a change in the chromatin structure such that proteins like RNA polymerases can gain access to the DNA and begin transcription. ${ }^{24}$ Scriptaid treatment improved the production of cloned mice ${ }^{24}$ and pigs, ${ }^{25,26}$ but it was not known if scriptaid treatment would improve the development of embryos generated from Xenopus egg extract-treated donor cells.

To introduce the extract reprogramming factor(s) into donor cells, the cell membrane must be permeabilized to allow transport of substances from the extract into the cytoplasm and the nucleus. Treatment of cells with digitonin selectively permeabilizes the plasma membrane due to its relatively high cholesterol content, whereas most other intracellular membranes, including the nuclear envelope (which is low in cholesterol), remain intact, and the cytoskeleton is largely undisturbed. After permeabilization, soluble proteins diffuse through the digitonin-induced pores in the plasma membrane, which are sufficient for passive diffusion of proteins up to $100 \mathrm{kDa} .^{27} \mathrm{In}$ porcine fibroblast cells, the permeabilization rates, as shown by propidium iodide incorporation, gradually increased from $5 \mu \mathrm{g} / \mathrm{mL}$ digitonin, and almost half of the cells were permeabilized at $10 \mu \mathrm{g} / \mathrm{mL}^{11}$ It has been also demonstrated that Xenopus oocyte extract decreased histone (H3K9) methylation in ovine ${ }^{21}$ but it was not known if different concentrations of digitonin along with Xenopus egg extract treatment would affect DNA methylation of donor cells.

Thus, the objectives of current study were (1) to determine the effects of Xenopus egg extract treatment on the donor cell DNA methylation status and the effects of different digitonin concentrations (10 and $15 \mu \mathrm{g} / \mathrm{mL}$ ) along with Xenopus egg extract treatment on DNA methylation; (2) to determine if treatment of somatic cells with Xenopus egg extract before nuclear transfer would improve subsequent development of SCNT embryos; and (3) to investigate if the combined two treatments, treating donor cells with Xenopus egg extract before nuclear transfer and scriptaid treatment of cloned embryos, would improve SCNT embryo development additively in pigs.

\section{Materials and Methods}

\section{Experimental design}

Experiment 1. Digitonin concentration and 5-methylcytosine DNA methylation status in donor cells. This experiment studied the effects of Xenopus egg extract treatment on the donor cell global DNA methylation status at days 0 and 4 after extract treatment. Along with extract treatment, two different concentrations of digitonin (10 and $15 \mu \mathrm{g} / \mathrm{mL})$ for cell permeabilization were also compared. Three treatment groups were included for each day of study, 10D+extract: $10 \mu \mathrm{g} / \mathrm{mL}$ digitonin permeabilization and Xenopus egg extract treatment; $15 \mathrm{D}+$ extract: $15 \mu \mathrm{g} / \mathrm{mL}$ digitonin permeabilization and Xenopus egg extract treatment; and the control group: $15 \mu \mathrm{g} / \mathrm{mL}$ digitonin permeabilization and no extract treatment. The cells were collected at the end of $2.5-\mathrm{h}$ resealing culture for day- 0 samples and at day 4 for day- 4 samples and processed for 5-methylcytosine $(5 \mathrm{MeC})$ staining as described below.

Experiment 2. Effects of donor cell treatment with Xenopus egg extract on fusion and cloned embryo development. To determine the effect of pretreatment of donor cells with Xenopus egg extract on SCNT embryo development, donor cells plated for 2 days were divided into two groups, the extract-treated and control group. The extract-treated cells were cultured with the Xenopus egg extract for $2 \mathrm{~h}$ after being permeabilized with $15 \mu \mathrm{g} / \mathrm{mL}$ digitonin, whereas the control was cultured in the Dulbecco's modified Eagle's medium (DMEM). Then, both groups of cells were cultured in the DMEM supplemented with $2 \mathrm{mM} \mathrm{CaCl}_{2}$ and $10 \%$ fetal bovine serum (FBS) at $38.5^{\circ} \mathrm{C}$ for $2.5 \mathrm{~h}$ to re-seal the membranes. Individual cells were injected under the zona pellucida of enucleated oocytes and then electrically fused. The cloned embryos were cultured as described below. Cleavage and blastocyst formation were checked on days 2 and 7 with the SCNT day as day 0 . The number of nuclei in the blastocysts was also determined at day 7 .

Experiment 3. Effects of combined treatment of donor cells with Xenopus egg extract before nuclear transfer and scriptaid treatment of cloned embryos on embryo development. This experiment determined if the combined two treatments, treating donor cells with Xenopus egg extract before SCNT and scriptaid treatment of cloned embryos after activation, would additively improve embryo development. After culture for 2 days, donor cells were incubated with the Xenopus egg extract for $2 \mathrm{~h}$ at room temperature after permeabilization with $15 \mu \mathrm{g} / \mathrm{mL}$ digitonin and then cultured in the DMEM supplemented with $2 \mathrm{mM} \mathrm{CaCl}_{2}$ and $10 \% \mathrm{FBS}$ at $38.5^{\circ} \mathrm{C}$ for $2.5 \mathrm{~h}$. SCNT was carried out as described below. The cloned embryos were divided into two groups and treated with 0 (extract control) or $500 \mathrm{nM}$ scriptaid (extract+scriptaid) for $14 \mathrm{~h}$. Embryos were washed and further cultured in porcine zygote medium 3 (PZM3) for 7 days. Cleavage and blastocyst formation were checked on days 2 and 7. The number of nuclei in the blastocysts was determined at day 7 .

\section{Chemicals and preparation of Xenopus egg extract}

All chemicals were purchased from Sigma Chemical Co., unless otherwise stated. 
Surgically extracted Xenopus ovaries were purchased from Nasco. Ovaries were washed five times in the Ringer's solution, dissected into small pieces using a pair of scissors, and placed into $100-\mathrm{mm}$ Petri dishes containing $15 \mathrm{~mL} 0.4 \%$ collagenase (type II) in the Ringer's solution on a rocking table at room temperature for about $2 \mathrm{~h}$. After complete digestion, oocytes were washed six times with the ND-96 buffer $\left(96 \mathrm{mM} \mathrm{NaCl}, 2 \mathrm{mM} \mathrm{KC1}, 1.8 \mathrm{mM} \mathrm{CaC1}_{2}, 1 \mathrm{mM} \mathrm{MgC1}_{2}\right.$, and $5 \mathrm{mM}$ HEPES, pH 7.6). Stage VI and V oocytes (the largest) were selected manually and induced to mature with $5 \mu \mathrm{g} / \mathrm{mL}$ progesterone for $8 \mathrm{~h}$, as described previously. ${ }^{28}$ Mature oocytes were sorted out by the appearance of an external white spot at the animal pole, washed twice in the ND-96 buffer, and two times in an extract buffer [100 mM $\mathrm{KCl}, 5 \mathrm{mM} \mathrm{MgC1}_{2}, 20 \mathrm{mM}$ HEPES, $1 \mathrm{mM}$ dithiothreitol, $300 \mu \mathrm{M}$ phenylmethanesulfluoride (PMSF), $5 \mu \mathrm{g} / \mathrm{mL}$ cytochalasin B (CB), and a protease inhibitor cocktail $(100 \times$, Sigma P8340), pH 7.5]. Oocytes were transferred into centrifuge tubes with a round bottom and allowed to settle. Excess buffer was removed. Then, the oocytes were centrifuged at $10,000 \mathrm{~g}$ for $10 \mathrm{~min}$ at $4^{\circ} \mathrm{C}$ using a super-speed centrifuge (Du Pont Co.). The contents of each tube were stratified into three main layers. The top yellow lipid was removed with a cotton swab; the middle ooplasmic layer was transferred to a clean centrifuge tube, and centrifuged at 10,000 $g$ for another $10 \mathrm{~min}$. The supernatant was again collected into a clean tube and re-centrifuged at 20,000 $\mathrm{g}$ for $40 \mathrm{~min}$. Supernatant (Xenopus egg extract) was collected and 5\% $(\mathrm{v} / \mathrm{v})$ glycerol was added. Aliquots of extracts were snap frozen in liquid nitrogen, and stored at $-80^{\circ} \mathrm{C}$ until use. Extract from one frog was used for this study.

\section{Primary cells establishment, donor cell permeabilization, and Xenopus egg extract treatment}

Ear fibroblast cells were established from enhanced green fluorescent protein (EGFP)-positive piglets ${ }^{29}$ as previously described. $^{30}$ Briefly, ear notches from 1-week-old EGFP piglets were recovered and rinsed three times with Dulbecco's phosphate-buffered saline (DPBS). The ear notches were cleaned, the hair removed, and minced into pieces. Minced tissue was digested with collagenase $(200 \mathrm{U} / \mathrm{mL})$ and DNase I (25 $\mathrm{kU} / \mathrm{mL}$ ) in the DMEM plus $15 \%$ FBS (Hyclone) for $4-5 \mathrm{~h}$ at $38.5^{\circ} \mathrm{C}$ and $5 \% \mathrm{CO}_{2}$ in air. After digestion and rinsing, the cell pellet was seeded in a $75-\mathrm{cm}^{2}$ culture flask and left to culture until the culture was confluent. Primary cultures were then frozen in FBS containing 10\% dimethyl sulfoxide (DMSO). Two days before nuclear transfer, EGFP fibroblasts were thawed and plated in a $25-\mathrm{cm}^{2}$ flask and grown to about $50 \%$ confluency. On the experiment day, cells were washed in $\mathrm{Ca}^{2+}$ - and $\mathrm{Mg}^{2+}$-free phosphate-buffered saline (PBS) and Hank's balanced salt solution (HBSS), and then permeabilized in HBSS containing 10 or $15 \mu \mathrm{g} / \mathrm{mL}$ digitonin at a concentration of two million cells per $1 \mathrm{~mL}$ for $2 \mathrm{~min}$ while kept on ice. Permeabilization was stopped by adding an excess of HBSS and centrifuging at $700 \mathrm{~g}$ for $5 \mathrm{~min}$.

The digitonin-permeabilized cells were incubated in the Xenopus egg extract containing an ATP-regenerating system $(2.5 \mathrm{mM}$ ATP, $125 \mu \mathrm{M}$ GTP, $62.5 \mu \mathrm{g} / \mathrm{mL}$ creatine kinase, $25 \mathrm{mM}$ phosphocreatine, and $1 \mathrm{mM}$ NTP [Roche]) for $2 \mathrm{~h}$ at room temperature ${ }^{31}$ and then cultured in the DMEM supplemented with $2 \mathrm{mM} \mathrm{CaCl}_{2}$ and $10 \% \mathrm{FBS}$ at $38.5^{\circ} \mathrm{C}$ for
$2.5 \mathrm{~h}$ for cell membranes to re-seal ${ }^{11}$ and to permit live cells to attach to the plate. A single-cell suspension was prepared by trypsinization of the cultured cells and resuspension in the oocyte manipulation medium (25 mM HEPES buffered tissue culture medium 199 (TCM199) with $3 \mathrm{mg} /$ $\mathrm{mL}$ bovine serum albumin [BSA]) before SCNT.

\section{Collection of porcine oocytes and in vitro maturation}

Ovaries were collected from prepubertal gilts at a local abattoir and transported to the laboratory at $37^{\circ} \mathrm{C}$. Cumulus oocyte complexes were aspirated from antral follicles (3-6 mm in diameter) with an 18-gauge needle attached to a $10-\mathrm{mL}$ syringe. The cumulus-oocyte complexes (COCs) in the follicular fluid were allowed to settle by gravity. The COCs were rinsed three times in the HEPES-buffered Tyrode medium containing $0.01 \%$ polyvinylalcohol (PVA)..$^{32}$ Only the COCs with multiple layers of intact cumulus cells and uniform ooplasm were selected for IVM. After washing in the in vitro maturation (IVM) medium, a group of 50-60 COCs was placed into each well of four-well plates (Nunc) containing $500 \mu \mathrm{L}$ of the IVM medium and cultured for $40-44 \mathrm{~h}$ at $38.5^{\circ} \mathrm{C}, 5 \% \mathrm{CO}_{2}$, in humidified air. The oocyte maturation (IVM) medium was TCM199 (Gibco BRL) supplemented with $0.1 \%$ PVA (w/v), $3.05 \mathrm{mM}$ D-glucose, $0.91 \mathrm{mM}$ sodium pyruvate, $10 \mu \mathrm{g} / \mathrm{mL}$ gentamicin, $0.57 \mathrm{mM}$ cysteine, $0.5 \mu \mathrm{g} /$ mL luteinizing hormone from sheep pituitary, $0.5 \mu \mathrm{g} / \mathrm{mL}$ follicle-stimulating hormone from porcine pituitary, and $10 \mathrm{ng} /$ mL epidermal growth factor. ${ }^{32}$ Matured oocytes were then vortexed in $0.1 \%$ hyaluronidase in an HEPES-buffered Tyrode medium containing $0.01 \%$ PVA for $4 \mathrm{~min}$ to remove the cumulus cells. Matured oocytes having an extruded first polar body with a uniform cytoplasm were used for SCNT.

\section{Somatic cell nuclear transfer and embryo culture}

Somatic cell nuclear transfer was carried out as previously described. ${ }^{26}$ Briefly, denuded oocytes were enucleated by aspirating the first polar body and MII chromosomes and a small amount of surrounding cytoplasm using a beveled glass pipette with an inner diameter of $17-20 \mu \mathrm{m}$. The medium for micromanipulation consisted of HEPES-buffered TCM199, $0.3 \%$ BSA, and $7.5 \mathrm{mg} / \mathrm{mL}$ of CB for enucleation and no $\mathrm{CB}$ for injection.

A single intact donor cell was injected into the perivitelline space and placed adjacent to the recipient cytoplasm. Oocytedonor cell couplets were placed into the embryo culture medium PZM3 ${ }^{33}$ until fusion and activation. The fusion of oocyte-donor cell couplets and cloned embryo activation were accomplished with two direct current pulses of $1.2 \mathrm{kV} / \mathrm{cm}$ for $30 \mu \mathrm{sec}$ with a 1-sec interval between provided by a BTX Electro-cell Manipulator 200 (BTX) in a fusion medium (0.3 M mannitol, $1.0 \mathrm{mM} \mathrm{CaCl}_{2}, 0.1 \mathrm{mM} \mathrm{MgCl}_{2}$, and $0.5 \mathrm{mM}$ HEPES, pH 7.3). Oocytes were then incubated for 20 min in PZM3 and evaluated for fusion under a stereomicroscope. Only the fused embryos (maximum 50 per well) were cultured in $500 \mu \mathrm{L}$ of PZM 3 at $38.5^{\circ} \mathrm{C}$ in humidified atmosphere of $5 \% \mathrm{CO}_{2}$ air.

\section{Determination of cell numbers}

All EGFP-expressing embryos represent true SCNT embryos (Fig. 1), and only green blastocysts found on day 7 from each 


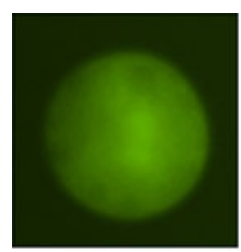

Zygote

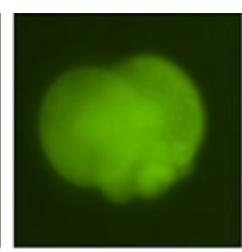

2-cell

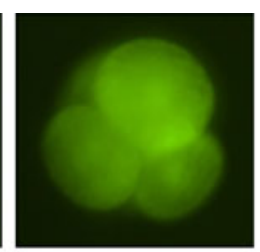

4-cell

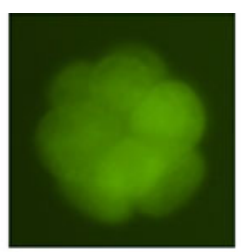

8 -cell

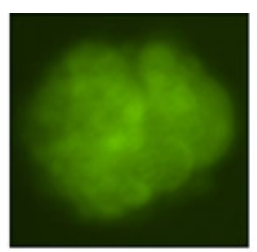

Morula

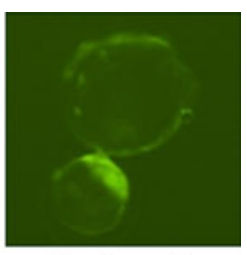

Blastocyst

FIG. 1. Representative somatic cell nuclear transfer embryos at different stages of development reconstructed by using enhanced green fluorescent protein fibroblast cells. Only green embryos were counted and used for data analysis.

group were stained with $4 \mu \mathrm{g} / \mathrm{mL}$ Hoechst 33342 for $15 \mathrm{~min}$ and mounted on a slide in $5 \mu \mathrm{L}$ glycerol. The total number of cells was counted by using a fluorescence microscope.

\section{Quantification of global DNA methylation in donor cells}

Differences in global methylation were determined by immune staining using antibodies directed against $5 \mathrm{MeC}$ (Eurogentec) as described by Kwon et al. ${ }^{34}$ with slight modification. Briefly, donor cells were plated on glass cover slips and cultured in the DMEM supplemented with $10 \%$ FBS for $2.5 \mathrm{~h}$ to attach for day- 0 samples and for 4 days for day- 4 samples. Cell samples were washed with $0.05 \%$ Tween 20 in PBS, fixed in $4 \%$ paraformaldehyde in PBS for $15 \mathrm{~min}$, and permeabilized with $0.2 \%$ Triton X-100 in PBS at room temperature for $15 \mathrm{~min}$. Samples were further treated with $2 \mathrm{M} \mathrm{HCl}$ at room temperature for $30 \mathrm{~min}$ and subsequently neutralized for $10 \mathrm{~min}$ with the HEPES-buffered Tyrode medium $(\mathrm{pH}$ 7.3). Cell samples were blocked overnight at $4^{\circ} \mathrm{C}$ in PBS containing $1 \%$ BSA and $0.05 \%$ Tween 20 . On day 2 , cells were sequentially incubated with $20 \mathrm{mg} / \mathrm{mL} 5 \mathrm{MeC}$ primary antibodies diluted at 1:500 and a Texas Red-conjugated goat anti-mouse $\operatorname{IgG}\left(1: 400\right.$ dilution) at $39^{\circ} \mathrm{C}$ for $1 \mathrm{~h}$. DNA was stained with $10 \mu \mathrm{g} / \mathrm{mL}$ Hoechst 33342 for $20 \mathrm{~min}$. Cover slips were mounted on glass slides in the Vecta shield antifade-mounting medium (Vector Laboratories). Cell samples were visualized by using a Nikon Elipse (E600) fluorescent microscope with a Texas Red filter. Images were captured by a Nikon DS-Fi1-mounted camera by using identical settings and an 8-sec exposure for all acquired images. Intensity within individual cells was determined by Image-Pro Plus software (v6.3, Media Cybernetics). The experiment was repeated three times, and negative controls were acquired by using normal serum without a primary antibody.

\section{Statistical analysis}

Data for the dependent variables, percent fusion, percent cleavage at day 2, percent blastocyst formation at day 7 , number of nuclei within the blastocyst-stage embryos, and intensity of $5 \mathrm{MeC}$ immune staining of donor cells were analyzed using the PROC MIXED procedure of SAS ${ }^{\circledR}$ software, ${ }^{35}$ with treatment and day in class as the main effects. The number of nuclei in blastocyst-stage embryos was square root transformed to approach a normal distribution. The experimental unit was the culture well in which cells were treated for the $5 \mathrm{MeC}$-staining analysis and droplets in which a group of embryos were cultured. In the results, the least-square means and the standard errors of means are presented. A probability of $p<0.05$ was considered to be statistically significant.

\section{Results}

\section{Effects of Xenopus oocyte extract treatment on DNA methylation in donor cells}

The DNA methylation status was determined using an antibody to $5 \mathrm{MeC}$; a decrease in $5 \mathrm{MeC}$ is indicative of demethylation at cytosine guanine $(\mathrm{CpG})$ dinucleotides, the most common areas on the DNA of mammals that methyl groups bind. ${ }^{36}$ A total of 1583 and 1175 cells from three treatment groups and three replicates were sampled, assayed, and analyzed at days 0 and 4, respectively. For the day- 0 cells, the intensity of $5 \mathrm{MeC}$ staining in the extract-treated cells was reduced in both the $10 \mathrm{D}+$ extract and $15 \mathrm{D}+$ extract groups compared to the $15 \mu \mathrm{g} / \mathrm{mL}$ digitonin-treated, but without extract-treated control group $(p<0.05)$ (Fig. 2A). Furthermore, when the digitonin level increased from 10 to $15 \mu \mathrm{g} / \mathrm{mL}$, the intensity of $5 \mathrm{MeC}$ staining in the $15 \mathrm{D}+$ extract group was lower than the $10 \mathrm{D}+$ extract group $(p<0.01)$. However, after the cells were cultured for four more days, the intensity of $5 \mathrm{MeC}$ staining in the cells increased from day 0 to day 4 , and there was no difference between the extract-treated and nonextract-treated control groups (Fig. 2B). Based on these results, the day- 0 cells treated with $15 \mu \mathrm{g} / \mathrm{mL}$ digitonin extract and the Xenopus egg extract were used for the nuclear transfer and embryo culture experiments.

\section{Effects of donor cell treatment with Xenopus egg extract on fusion and cloned embryo development}

A total of 718 couplets were produced from seven replicates, and 573 fused couplets were cultured in the PZM3 medium for 7 days. There was no difference in the percentage of fused couplets out of total embryos reconstructed by SCNT or the percentage of cleaved embryos out of fused couplets between the extract-treated and control groups. However, there was an increase in the percentage of fused couplets that developed to the blastocyst stage in the Xenopus egg extract-treated group compared to the nontreated control $(p=0.01)$. Furthermore, the cell number in day-7 blastocyst embryos in the extract-treated group was higher than the control $(p=0.05)$ (Table 1).

\section{Effects of combined treatments of donor cells with Xenopus egg extract before SCNT and scriptaid treatment of cloned embryos on embryo development}

Using the same Xenopus egg extract-treated cells, a total of 920 couplets were reconstructed from seven replicates, and 787 fused couplets were divided into two groups. They were treated with 0 (extract control without scriptaid) or 
A
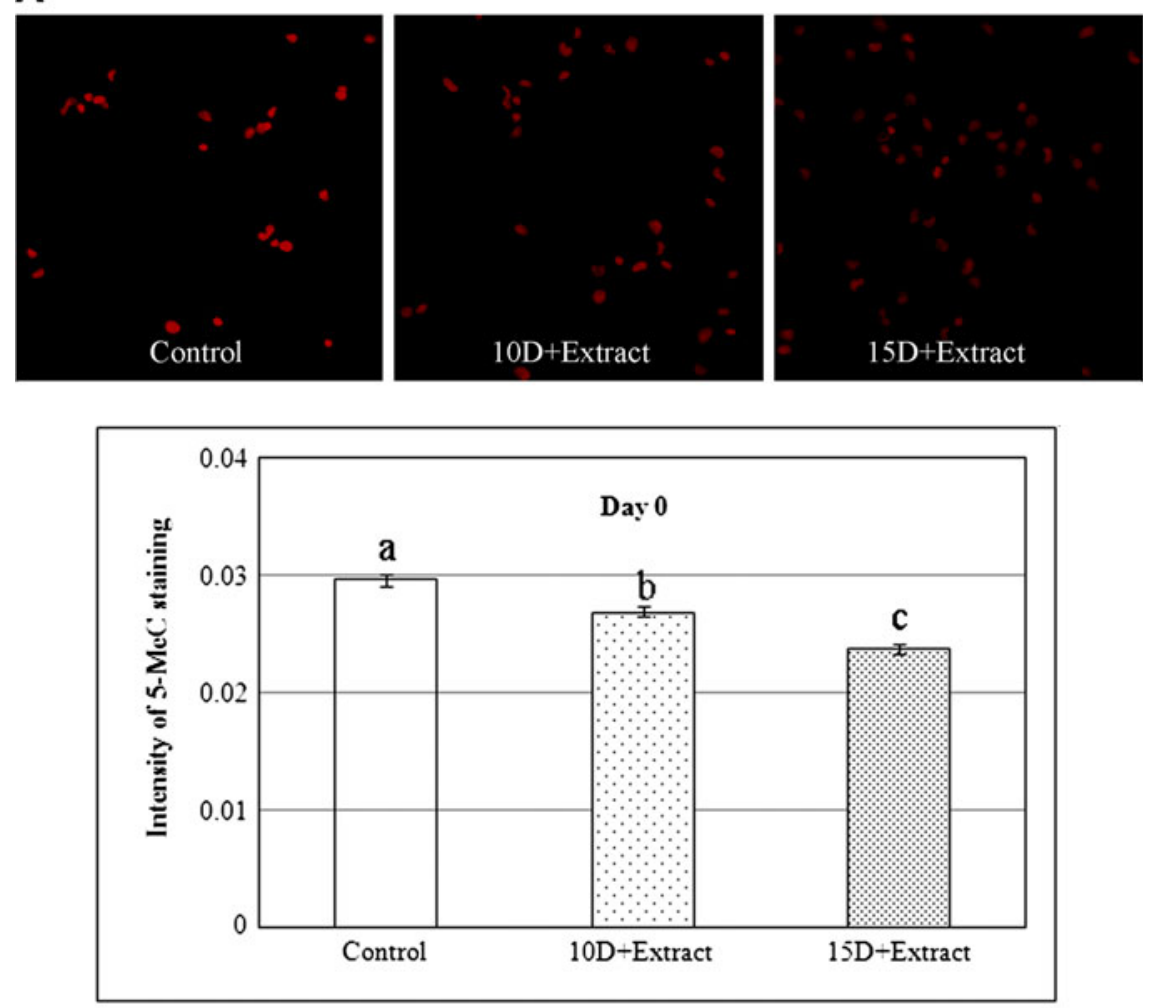

B
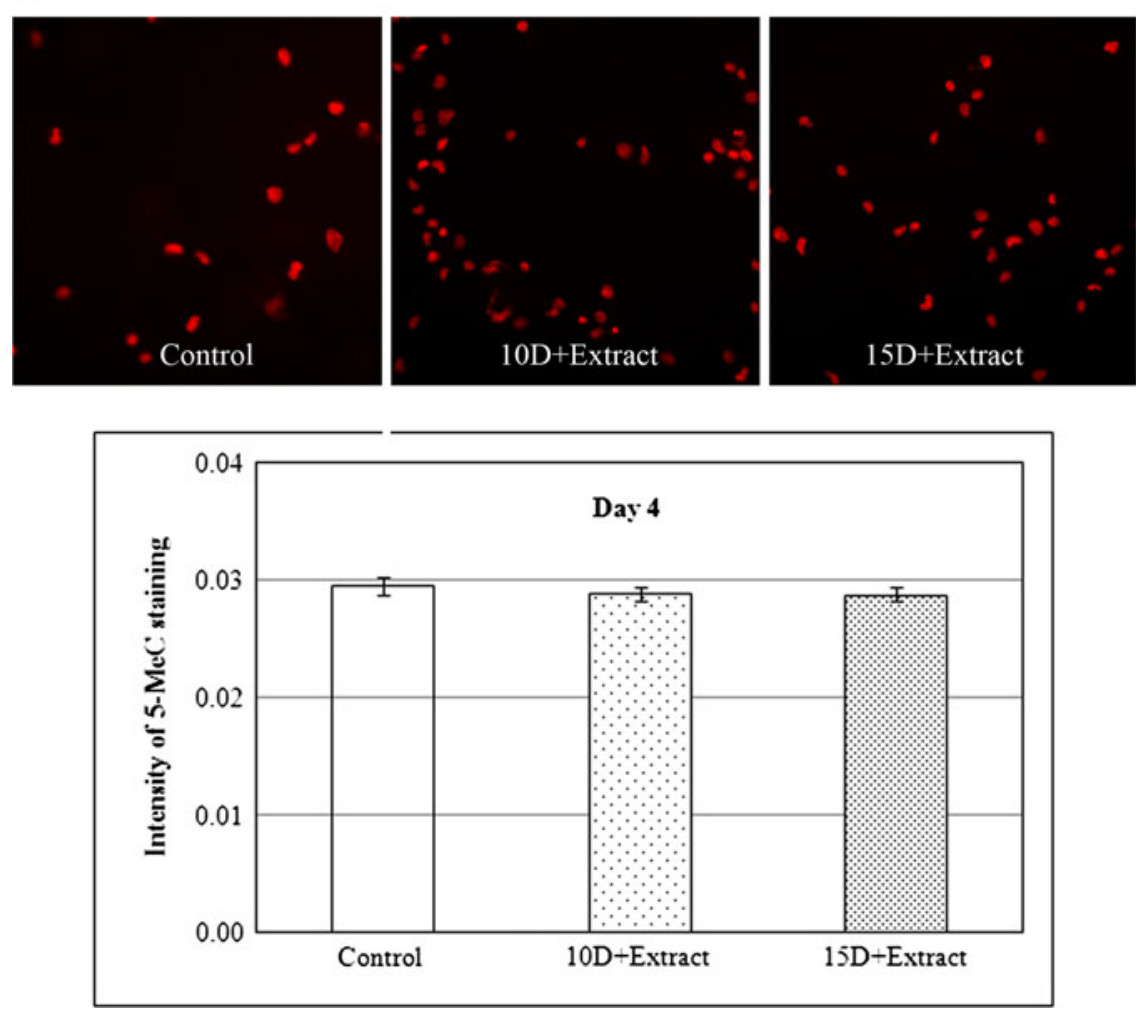

FIG. 2. Quantitative analysis of the DNA methylation status detected by $5 \mathrm{MeC}$ immunostaining in the control and Xenopus egg extract-treated cells (10D + extract: $10 \mu \mathrm{g} / \mathrm{mL}$ digitonin permeabilization of cells and Xenopus egg extract treatment; $15 \mathrm{D}+$ extract: $15 \mu \mathrm{g} / \mathrm{mL}$ digitonin permeabilization and Xenopus egg extract treatment) at days 0 (A) and 4 (B). The level of methylation is reported in arbitrary units and was detected using Texas Red-labeled antibodies (second) bound to primary antibodies specific to $5 \mathrm{MeC} . \mathrm{a}, \mathrm{b}$, and c: Intensity of $5 \mathrm{Mec}$ staining in columns with different letters differ $(\mathrm{a}, \mathrm{b}: p<0.05 ; \mathrm{a}, \mathrm{c}$ and $\mathrm{b}$, c: $p<0.01)$. 5MeC, 5-methylcytosine. 
Table 1. Fusion Rate and Cloned Embryo Development Reconstructed from $X_{\text {enopus Egg Extract-Treated and Nontreated Donor Cells }}$

\begin{tabular}{lcccccc}
\hline & \multicolumn{2}{c}{ No. of oocytes } & & & SCNT embryo development \\
\cline { 2 - 3 } $\begin{array}{l}\text { Xenopus egg } \\
\text { extract treatment }\end{array}$ & $\begin{array}{c}\text { Total } \\
\text { enucleated }\end{array}$ & $\begin{array}{c}\text { Fused } \\
(\% \text { enucleated })\end{array}$ & & $\begin{array}{c}\text { Cleaved } \\
(\% \text { fused })\end{array}$ & $\begin{array}{c}\text { Blastocyst } \\
(\% \text { fused })\end{array}$ & $\begin{array}{c}\text { No. of nuclei } \\
\text { in blastocysts }\end{array}$ \\
\hline $\begin{array}{l}\text { Control } \\
\text { Treated }\end{array}$ & 305 & $250(82.3 \pm 3.0)$ & & $185(72.2 \pm 3.7)$ & $25(9.1 \pm 1.9)^{*}$ & $36.0 \pm 3.6^{* *}$ \\
\hline
\end{tabular}

${ }^{*} p=0.01$

$* * p=0.05$

SCNT, somatic cell nuclear transfer.

500 nM scriptaid (extract + scriptaid group) for $14 \mathrm{~h}$ after activation. Embryos were then washed and cultured in the PZM3 medium for 7 days. There was no difference in the percentage of fused couplets out of total embryos reconstructed by SCNT or the percentage of cleaved embryos out of fused couplets between the scriptaid-treated and control groups. Scriptaid treatment (extract+scriptaid) increased the percentage of fused couplets that developed to the blastocyst stage compared to the nonscriptaid-treated extract control $(p<0.01)$. In other words, the combined treatment of donor cells with the Xenopus egg extract before nuclear transfer and scriptaid treatment of cloned embryos enhanced embryo development to blastocyst stage compared to the Xenopus egg extract treatment alone. Also, there was a tendency of higher cell number in day-7 blastocyst-stage embryos in the extract- and scriptaid-treated group compared to the extract-only control $(p=0.06)$ (Table 2).

\section{Discussion}

The metaphase II (MII)- and germinal vesicle (GV)-stage oocyte cytoplasm from both amphibians and mammals is different in their reprogramming capabilities ${ }^{37,38}$ and in their effects on embryo development. ${ }^{22}$ Studies by Tang et al. ${ }^{22}$ showed that bovine donor cells treated with the bovine MII-stage oocyte extract increased blastocyst development, whereas an increase was not observed in GV-stage oocyte extract-treated cells, compared to the nontreated controls. Furthermore, MII oocytes have been used as recipient cells for nuclear transfer of somatic cells in mammals, which also suggests that they would be a reasonable source of extracts for inducing nuclear remodeling and reprogramming before nuclear transfer. In contrast, GV oocytes are considered to be inadequate for use as recipients, ${ }^{39}$ though GV oocytes also have a reprogramming potential. ${ }^{40}$ Very recently, Miyamoto et al. ${ }^{41}$ showed that porcine MII oocyte extract was able to displace transcription factors from donor nuclei and deacetylate the histone tails of somatic nuclei. ${ }^{41}$ These reprogramming events related to the erasure of gene-expression memories are also observed in somatic nuclei transferred to MII oocytes, suggesting that some reprogramming events can be reproduced in the oocyte extracts. In the current study, Xenopus egg extract was prepared from MII oocytes. Xenopus egg extract treatment decreased global DNA methylation in donor cells. Furthermore, Xenopus egg extract treatment increased the cloned embryo development to blastocyst and increased cell numbers in the embryos. These results further demonstrated that Xenopus egg extract from mature MII oocytes has beneficial effects on donor cell reprogramming before nuclear transfer and on development of cloned embryos that are reconstructed from treated donor cells. It also supports the observations that Xenopus oocyte extract treatment improved blastocyst formation in handmade pig clone embryos ${ }^{23}$ and the birth rate from SCNT embryos in the ovine. ${ }^{21}$

A previous study in ovine demonstrated that Xenopus extract treatment reduced methylation of histone $\mathrm{H} 3 \mathrm{~K} 9$, but not DNA methylation detected by $5 \mathrm{MeC}$ staining. ${ }^{21}$ In the current study, in the pig, the DNA methylation was reduced after extract treatment as reflected by decreased $5 \mathrm{MeC}$ staining. The discrepancy could be explained by the species and a different source of extract (GV vs. MII stage of Xenopus oocytes). Reprogramming of the somatic nuclei takes place right after nuclear transfer and continues until later embryo development. ${ }^{14,42}$ It was hypothesized that the donor cell nuclei may not have enough time to remodel and reprogram to a pluripotent status, thus may not remodel sufficiently, and results in a low cloning efficiency. It was further hypothesized that pretreatment of donor cells with Xenopus egg extract would provide initial remodeling to the donor cell nucleus before SCNT and would enhance the cloned embryo development. Xenopus extract contains many factors that may

Table 2. Fusion Rate and Development of Embryos Reconstructed from $X_{\text {enopus }}$ Egg Extract-Treated Donor Cells and then Treated With 0 (Control) or 500 NM SCRIPTAid For $14 \mathrm{H}$

\begin{tabular}{|c|c|c|c|c|c|}
\hline \multirow[b]{2}{*}{ Scriptaid treatment } & \multicolumn{2}{|c|}{ No. of oocytes } & \multicolumn{3}{|c|}{ SCNT embryo development } \\
\hline & Total enucleated & Fused (\% enucleated) & Cleaved (\% fused) & Blastocyst (\% fused) & No. of nuclei in blastocysts \\
\hline Control & 413 & $344(81.2 \pm 3.8)$ & $252(75.2 \pm 4.0)$ & $50(15.3 \pm 0.9)^{*}$ & $36.0 \pm 2.6^{* *}$ \\
\hline Scriptaid-treated & 507 & $443(88.8 \pm 3.8)$ & $352(77.9 \pm 4.0)$ & $101(22.5 \pm 0.9)^{*}$ & $40.9 \pm 1.8^{* *}$ \\
\hline
\end{tabular}

${ }^{*} p<0.01$.

$* * p=0.06$. 
contribute to the decreased global DNA methylation and enhanced embryo development. Such factors have been identified, and they are involved in nuclear remodeling and reprogramming, such as nucleosomal adenosine triphosphatase (ATPase) ISWI, ${ }^{43}$ FRGY2a $/ b^{44}$ ATPase BRG1, ${ }^{31}$ acidic nuclear protein nucleoplasmin (a decondensation factor), ${ }^{45}$ and linker Histone B4. ${ }^{12}$ Byrne et al. ${ }^{40}$ showed that somatic nuclei could express pluripotent marker genes, such as Oct4, after nuclei of mouse thymocytes and human blood lymphocytes were injected into GV-stage Xenopus oocytes. ${ }^{40}$ These studies suggest that nuclear reprogramming processes are highly conserved among species. Reprogramming factors have been mainly identified in Xenopus. This is because Xenopus eggs and oocytes are extremely large $(1.2 \mathrm{~mm}$ in diameter $)$ and easily accessible, compared to mammalian oocytes (100 $\mu \mathrm{m}$ in diameter). While the roles of some reprogramming factors in nuclear remodeling and transcriptional reprogramming have been reported, it has not been demonstrated that these factors are crucial for nuclear reprogramming in cloned embryos during embryonic development. In the current study, it was demonstrated that pretreatment of donor cells with Xenopus egg extract enhanced cloned embryo development, which supports the hypothesis tested. DNA demethylation is necessary for epigenetic reprogramming of somatic cell nuclei, ${ }^{46}$ because epigenetic mechanisms play an important role in developmental competence of reconstructed embryos. $^{7}$ A reduction of DNA methylation after egg extract treatment confirmed its role in nuclear reprogramming and may be one of the major mechanisms for the beneficial effects on cloned embryo development in the current study. In addition, Xenopus egg extract may have changed the chromatin structure of donor nuclei so that it was easier for the recipient cytoplasm to remodel and reprogram the donor cell nucleus.

One critical limitation for the reprogramming factors to penetrate cell membrane and act on the nucleus was the size of pores in the membrane. As reported by Liu et al. ${ }^{23}<10 \%$ of cells would stain positive with Texas Red (conjugated molecular weight: 70,000 ) when they were treated with $7.5 \mu \mathrm{g} / \mathrm{mL}$ digitonin. The permeabilization rate increased rapidly when digitonin concentration was increased from 10 to $30 \mu \mathrm{g} / \mathrm{mL}{ }^{23}$ However, high-digitonin treatment would reduce the recovery and survival rate of treated cells. ${ }^{11,23}$ In the current study, medium concentrations of 10 and $15 \mu \mathrm{g} / \mathrm{mL}$ digitonin were chosen, and their effects on global DNA methylation status were evaluated. It was found that permeabilization with $15 \mu \mathrm{g} / \mathrm{mL}$ digitonin decreased the DNA methylation status further after Xenopus egg extract treatment, compared to the $10 \mu \mathrm{g} / \mathrm{mL}$ digitonin group and the control. Thus, the concentration of $15 \mu \mathrm{g} / \mathrm{mL}$ was an optimal concentration for permeabilizing donor cells and was used for nuclear transfer experiments in the current study.

Scriptaid is an HDACi that belongs to an existing class of hydroxamic acid-containing HDAC inhibitors. ${ }^{47}$ It is thought that HDAC inhibitors can induce hyperacetylation of the core histones, resulting in structural changes in chromatin that permit transcription, as well as reduction of DNA methylation of the somatic cell-derived genome after nuclear transfer, ${ }^{48}$ which is necessary for genome reprogramming. ${ }^{46,49}$ Increased acetylation of histones leads to relaxed binding of the nucleosome to DNA and/or linker histones, relaxation of chromatin structures, and formation of a transcriptionally permissive state. ${ }^{50,51}$ Histone deacetylation, frequently followed by histone methylation, establishes a base for highly repressive chromatin structures such as heterochromatin. ${ }^{52}$ Scriptaid treatment induces hyperacetylation, decreases DNA methylation, and thus activates genes that are key for development. ${ }^{53}$ It also corrects gene expression in the SCNT blastocyst embryos. ${ }^{54}$ Scriptaid treatment alone increased the percentage of blastocyst and cloning efficiency in pigs. ${ }^{25,26}$ The higher blastocyst formation in scriptaid-treated SCNT embryos from the current study also supports these observations. Compared to the Xenopus extract treatment control in the current study, the combined treatment of Xenopus extract of donor cells and scriptaid treatment of reconstructed embryos additively increased blastocyst formation, which indicates that both treatments could be used together to improve the embryo development in pigs.

\section{Summary}

Treatment of donor cells with extract prepared from mature Xenopus oocytes reduced global DNA methylation. A digitonin concentration at $15 \mu \mathrm{g} / \mathrm{mL}$ for cell permeabilization before Xenopus egg extract treatment further decreased DNA methylation compared to the $10 \mu \mathrm{g} / \mathrm{mL}$ digitonin treatment group. More embryos reconstructed with Xenopus egg extract-treated donor cells developed to the blastocyst stage than the nontreated control. Furthermore, the current study was the first to report that combined treatment of donor cells with Xenopus egg extract before somatic cell nuclear transfer and scriptaid treatment of cloned embryos increased SCNT embryo development in pigs.

\section{Acknowledgments}

We would like to thank Dr. K.M. Whitworth for providing EGFP fibroblast cells, L.D. Spate for assistance with this study, Dr. D.H. Keisler for providing progesterone and helping with solution preparation for frog oocyte maturation, Dr. Mark Ellersieck for helping with data analysis, and many others from Dr. Prather's lab for helping with ovary transportation and aspiration. This research was supported by the National Natural Science Foundation of China (No. 31071311), Natural Science Foundation of Fujian Province of China (No. 2009J06017), and NIH grants U42 RR018877 and R01 RR013438.

\section{Author Disclosure Statement}

The authors declare that no conflicting financial interests exist.

\section{References}

1. Ng YF, Chan $\mathrm{HH}, \mathrm{Chu} \mathrm{PH}$, et al. Multifocal electroretinogram in rhodopsin P347L transgenic pigs. Invest Ophthalmol Vis Sci. 2008;49:2208-2215.

2. Rogers CS, Stoltz DA, Meyerholz DK, et al. Disruption of the CFTR gene produces a model of cystic fibrosis in newborn pigs. Science. 2008;321:1837-1841.

3. Welsh MJ, Rogers CS, Stoltz DA, et al. Development of a porcine model of cystic fibrosis. Trans Am Clin Climatol Assoc. 2009;120:149-162.

4. Kolber-Simonds D, Lai L, Watt SR, et al. Production of alpha1,3-galactosyltransferase null pigs by means of nuclear 
transfer with fibroblasts bearing loss of heterozygosity mutations. Proc Natl Acad Sci USA. 2004;101:7335-7340.

5. Prather RS, Hawley RJ, Carter DB, et al. Transgenic swine for biomedicine and agriculture. Theriogenology. 2003;59:115123.

6. Lai L, Kang JX, Li R, et al. Generation of cloned transgenic pigs rich in omega-3 fatty acids. Nat Biotechnol. 2006;24:435-436.

7. Whitworth KM, Prather RS. Somatic cell nuclear transfer efficiency: how can it be improved through nuclear remodeling and reprogramming? Mol Reprod Dev. 2010;77:1001-1015.

8. Latham KE. Early and delayed aspects of nuclear reprogramming during cloning. Biol Cell. 2005;97:119-132.

9. Wilmut I, Schnieke AE, McWhir J, et al. Viable offspring derived from fetal and adult mammalian cells. Nature. 1997; 385:810-813.

10. Onishi A, Iwamoto M, Akita T, et al. Pig cloning by microinjection of fetal fibroblast nuclei. Science. 2000;289:1188-1190.

11. Miyamoto K, Yamashita T, Tsukiyama T, et al. Reversible membrane permeabilization of mammalian cells treated with digitonin and its use for inducing nuclear reprogramming by Xenopus egg extracts. Cloning Stem Cells. 2008;10: 535-542.

12. Jullien J, Astrand C, Halley-Stott RP, et al. Characterization of somatic cell nuclear reprogramming by oocytes in which a linker histone is required for pluripotency gene reactivation. Proc Natl Acad Sci USA. 2010;107:5483-5488.

13. Gao S, Gasparrini B, McGarry M, et al. Germinal vesicle material is essential for nucleus remodeling after nuclear transfer. Biol Reprod. 2002;67:928-934.

14. Teranishi T, Tanaka M, Kimoto S, et al. Rapid replacement of somatic linker histones with the oocyte-specific linker histone H1foo in nuclear transfer. Dev Biol. 2004;266:76-86.

15. Bourc'his D, Le Bourhis D, Patin D, et al. Delayed and incomplete reprogramming of chromosome methylation patterns in bovine cloned embryos. Curr Biol. 2001;11:1542-1546.

16. Miyamoto K, Furusawa T, Ohnuki M, et al. Reprogramming events of mammalian somatic cells induced by Xenopus laevis egg extracts. Mol Reprod Dev. 2007;74:1268-1277.

17. Egli D, Sandler VM, Shinohara ML, et al. Reprogramming after chromosome transfer into mouse blastomeres. Curr Biol. 2009;19:1403-1409.

18. Cowan CA, Atienza J, Melton DA, et al. Nuclear reprogramming of somatic cells after fusion with human embryonic stem cells. Science. 2005;309:1369-1373.

19. Bru T, Clarke C, McGrew MJ, et al. Rapid induction of pluripotency genes after exposure of human somatic cells to mouse ES cell extracts. Exp Cell Res. 2008;314:2634-2642.

20. Bui HT, Wakayama S, Kishigami S, et al. The cytoplasm of mouse germinal vesicle stage oocytes can enhance somatic cell nuclear reprogramming. Development. 2008;135:39353945.

21. Rathbone AJ, Fisher PA, Lee JH, et al. Reprogramming of ovine somatic cells with Xenopus laevis oocyte extract prior to SCNT improves live birth rate. Cell Reprogram. 2010; 12:609-616.

22. Tang S, Wang Y, Zhang D, et al. Reprogramming donor cells with oocyte extracts improves in vitro development of nuclear transfer embryos. Anim Reprod Sci. 2009;115:1-9.

23. Liu Y, Ostrup O, Li J, et al. Increased blastocyst formation of cloned porcine embryos produced with donor cells pretreated with Xenopus egg extract and/or digitonin. Zygote. 2011;21:61-66.

24. Van Thuan N, Bui HT, Kim JH, et al. The histone deacetylase inhibitor scriptaid enhances nascent mRNA production and rescues full-term development in cloned inbred mice. Reproduction. 2009;138:309-317.

25. Zhao J, Ross JW, Hao Y, et al. Significant improvement in cloning efficiency of an inbred miniature pig by histone deacetylase inhibitor treatment after somatic cell nuclear transfer. Biol Reprod. 2009;81:525-530.

26. Zhao J, Hao Y, Ross JW, et al. Histone deacetylase inhibitors improve in vitro and in vivo developmental competence of somatic cell nuclear transfer porcine embryos. Cell Reprogram. 2010;12:75-83.

27. Adam SA, Sterne-Marr R, Gerace L. Nuclear protein import using digitonin-permeabilized cells. Methods Enzymol 1992; 219:97-110.

28. Sagata N, Oskarsson M, Copeland T, et al. Function of c-mos proto-oncogene product in meiotic maturation in Xenopus oocytes. Nature. 1988;335:519-525.

29. Whitworth KM, Li R, Spate LD, et al. Method of oocyte activation affects cloning efficiency in pigs. Mol Reprod Dev. 2009;76:490-500.

30. Lai L, Prather RS. Production of cloned pigs by using somatic cells as donors. Cloning Stem Cells. 2003;5:233-241.

31. Hansis C, Barreto G, Maltry N, et al. Nuclear reprogramming of human somatic cells by Xenopus egg extract requires BRG1. Curr Biol. 2004;14:1475-1480.

32. Katayama M, Rieke A, Cantley T, et al. Improved fertilization and embryo development resulting in birth of live piglets after intracytoplasmic sperm injection and in vitro culture in a cysteine-supplemented medium. Theriogenology. 2007; 67:835-847.

33. Yoshioka K, Suzuki C, Tanaka A, et al. Birth of piglets derived from porcine zygotes cultured in a chemically defined medium. Biol Reprod. 2002;66:112-119.

34. Kwon DJ, Park CK, Yang BK, et al. Control of nuclear remodelling and subsequent in vitro development and methylation status of porcine nuclear transfer embryos. Reproduction. 2008;135:649-656.

35. Statistical Analysis Systems. SAS/STAT User's Guide (V9.2). Statistical Analysis Systems Institute, Inc.: Cary, NC. 2008.

36. Chen ZX, Riggs AD. DNA methylation and demethylation in mammals. J Biol Chem. 2011;286:18347-18353.

37. Alberio R, Johnson AD, Stick R, et al. Differential nuclear remodeling of mammalian somatic cells by Xenopus laevis oocyte and egg cytoplasm. Exp Cell Res. 2005;307:131-141.

38. Miyamoto K, Tsukiyama T, Yang Y, et al. Cell-free extracts from mammalian oocytes partially induce nuclear reprogramming in somatic cells. Biol Reprod. 2009;80:935-943.

39. Gao S, Chung YG, Parseghian MH, et al. Rapid H1 linker histone transitions following fertilization or somatic cell nuclear transfer: evidence for a uniform developmental program in mice. Dev Biol. 2004;266:62-75.

40. Byrne JA, Simonsson S, Western PS, et al. Nuclei of adult mammalian somatic cells are directly reprogrammed to oct4 stem cell gene expression by amphibian oocytes. Curr Biol. 2003;13:1206-1213.

41. Miyamoto K, Nagai K, Kitamura N, et al. Identification and characterization of an oocyte factor required for development of porcine nuclear transfer embryos. Proc Natl Acad Sci USA. 2011;108:7040-7045.

42. Bao S, Miyoshi N, Okamoto I, et al. Initiation of epigenetic reprogramming of the $X$ chromosome in somatic nuclei transplanted to a mouse oocyte. EMBO Rep. 2005;6:748-754.

43. Kikyo N, Wade PA, Guschin D, et al. Active remodeling of somatic nuclei in egg cytoplasm by the nucleosomal ATPase ISWI. Science. 2000;289:2360-2362. 
44. Gonda K, Fowler J, Katoku-Kikyo N, et al. Reversible disassembly of somatic nucleoli by the germ cell proteins FRGY2a and FRGY2b. Nat Cell Biol. 2003;5:205-210.

45. Tamada H, Van Thuan N, Reed P, et al. Chromatin decondensation and nuclear reprogramming by nucleoplasmin. Mol Cell Biol. 2006;26:1259-1271.

46. Simonsson S, Gurdon J. DNA demethylation is necessary for the epigenetic reprogramming of somatic cell nuclei. Nat Cell Biol 2004;6:984-990.

47. Su GH, Sohn TA, Ryu B, et al. A novel histone deacetylase inhibitor identified by high-throughput transcriptional screening of a compound library. Cancer Res 2000;60: 3137-3142.

48. Kishigami S, Mizutani E, Ohta H, et al. Significant improvement of mouse cloning technique by treatment with trichostatin A after somatic nuclear transfer. Biochem Biophys Res Commun. 2006;340:183-189.

49. Armstrong L, Lako M, Dean W, et al. Epigenetic modification is central to genome reprogramming in somatic cell nuclear transfer. Stem Cells. 2006; 24:805-814.

50. Hebbes TR, Thorne AW, Crane-Robinson C. A direct link between core histone acetylation and transcriptionally active chromatin. EMBO J. 1988;7:1395-1402.

51. Lee DY, Hayes JJ, Pruss D, et al. A positive role for histone acetylation in transcription factor access to nucleosomal DNA. Cell 1993;72:73-84.
52. Eberharter A, Becker PB. Histone acetylation: a switch between repressive and permissive chromatin. Second in review series on chromatin dynamics. EMBO Rep. 2002;3:224-229.

53. Cervoni N, Szyf M. Demethylase activity is directed by histone acetylation. J Biol Chem. 2001;276:40778-40787.

54. Whitworth KM, Zhao J, Spate LD, et al. Scriptaid corrects gene expression of a few aberrantly reprogrammed transcripts in nuclear transfer pig blastocyst stage embryos. Cell Reprogram 2011;13:191-204.

Address correspondence to: Randall S. Prather, PhD

Division of Animal Sciences

National Swine Resource and Research Center University of Missouri

Columbia, MO 65211

E-mail: pratherr@missouri.edu

Xiaoyu Yang, PhD

Center of Cell Developmental Biology College of Preclinical Medicine

Fujian Medical University

FuZhou 350004, P.R. China

E-mail: yxyfj@163.com 